\title{
ADSORPTION OF HEXAVALENT CHROMIUM FROM AQUEOUS SOLUTIONS USING ACID ACTIVATED OF NATURAL ZEOLITE COLLECTED FROM ENDE-FLORES, INDONESIA
}

\author{
Yantus A.B Neolaka ${ }^{1,2}$, Eka B.S Kalla ${ }^{3}$, Ganden Supriyanto ${ }^{4, *}$, Suyanto ${ }^{4}$ \\ and Ni Nyoman Tri Puspaningsih ${ }^{4}$ \\ ${ }^{1}$ Mathematics and Natural Science Doctoral Program, Faculty of Science and Technology, \\ Airlangga University, Mulyorejo, Surabaya, 60115, Indonesia. \\ ${ }^{2}$ Chemical Education, Mathematics and Natural Science Education Department, Faculty of \\ Education and Teachers Training, University of Nusa Cendana, Kupang, 85001, Nusa Tengara \\ Timur, Indonesia. \\ ${ }^{3}$ Magister of Chemical Science, Department of Chemistry, Faculty of Science and Technology, \\ Airlangga University, Mulyorejo, Surabaya, 60115, Indonesia. \\ ${ }^{4}$ Department of Chemistry, Faculty of Science and Technology, Airlangga University, \\ Mulyorejo, Surabaya, 60115, Indonesia. \\ *E-mail: ganden-s@fst.unair.ac.id
}

\begin{abstract}
Natural zeolite collected from Ende-Flores Indonesia was characterized and activated with acid solution for Cr(VI) adsorption from aqueous solution. This natural zeolite is mainly composed of quartz and 50\% mordenite. The kinetic adsorption modeling was fitted best with the pseudo-second-order model, whereas isotherm adsorption followed the Langmuir model with the maximum adsorption (Qmax) of NZ and ANZ are $0.189 \mathrm{mg} / \mathrm{g}$ and $1.040 \mathrm{mg} / \mathrm{g}$. Moreover the ANZ was favorable for adsorption of $\mathrm{Cr}(\mathrm{VI})$ respectively.

Keywords: Natural zeolite, acid activated, $\mathrm{Cr}(\mathrm{VI})$ adsorption, kinetic, isotherm.
\end{abstract}

(c) RASĀYAN. All rights reserved

\section{INTRODUCTION}

Hexavalent Chromium ( $\mathrm{Cr}(\mathrm{VI})$ is one of the most dangerous heavy metal ion that receives high attention to be removed from wastewaters before getting discharged into the aquatic environment. Generally, the majority of chromium are found in forms of $\mathrm{Cr}(\mathrm{III})$ and $\mathrm{Cr}(\mathrm{VI})$ in aquatic environment ${ }^{1}$. $\mathrm{Cr}$ (III) is commonly less toxic and has been known to be essential in metabolism of glucose in mammals ${ }^{2}$. Cr(VI) is highly toxic and suspected as carcinogenic agent because it can modifies the process of DNA transcription causing chromosomal aberrations ${ }^{3}$. Furthermore, it can cause epidermal irritation and kidney and gastric damage ${ }^{4}$. Many processes have been used for the removal of $\mathrm{Cr}(\mathrm{VI})$ from industrial effluents namely membrane filtration, chemical precipitation, adsorption and ion exchange. Adsorption is one of most frequently methods used for $\mathrm{Cr}(\mathrm{VI})$ removal from aqueous solutions because of their economical and effective treatments. Many adsorbents have been developed for the $\mathrm{Cr}(\mathrm{VI})$ adsorption from aqueous samples such as non-conventional adsorbent (activated carbon) $)^{5,6}$, granular activated charcoal (GAC) ${ }^{7}$ and zeolites (natural and synthetic zeolite) ${ }^{1}$.

Natural zeolite is one of the adsorbent used in adsorption of $\mathrm{Cr}(\mathrm{VI})$ because of its effective performance and low cost ${ }^{1}$. Generally, natural zeolite collected from different places has different characteristics. These unique characteristics of natural zeolite (NZ) are probably attributed to the differences in the geological formation of zeolite sources ${ }^{8-11}$. Therefore, each special zeolite material has its own special characteristics 
and still requires to be observed individually ${ }^{8}$. Recently, the modified Ende-Flores Natural zeolite use hydrothermal method for adsorption a cationic dye have been reported ${ }^{12}$. They used a base solution to activate the NZ. We report, in this paper, an investigation on adsorption of hexavalent chromium from aqueous solution using an acid activated of Indonesia (Ende-Flores) natural zeolite. Kinetic and isotherm adsorption of $\mathrm{Cr}(\mathrm{VI})$ in batch system were also studied and reported.

\section{Material and Methods}

\section{EXPERIMENTAL}

1,5-diphenylcarbazide, potassium dichromate, $\mathrm{HF}, \mathrm{NH}_{4} \mathrm{Cl}, \mathrm{H}_{2} \mathrm{SO}_{4}, \mathrm{AgNO}_{3} \mathrm{NaOH}$ and $\mathrm{HCL}$ were purchased from Merck (Singapore). Aqua demineralization were prepared in our laboratory. Natural zeolite was collected from Ende Flores Nusa Tenggara Timur Indonesia.

\section{Preparation and Activation of Natural Zeolite}

The natural zeolite (NZ) was grounded and sieved with a 150 mesh sieves. The material was then washed with aqua demineralization to remove any non-adhesive impurities and stirred at $70{ }^{\circ} \mathrm{C}$. Then, the natural zeolite was filtered and dried in an oven at $105^{\circ} \mathrm{C}$ for 24 hours in order to keep anhydrous. The NZ activation process was carried out by mixing NZ powder with $1 \% \mathrm{HF}$ for 1 hour then washed with aqua demineralization, filtered and dried in an oven at $120{ }^{\circ} \mathrm{C}$ for 3 hours. Next, the activated $\mathrm{NZ}$ was washed again with $6 \mathrm{M} \mathrm{HCl}$ for 30 minutes, stirred at $50{ }^{\circ} \mathrm{C}$, filtered and washed repeatedly with aqua demineralization. The activated $\mathrm{NZ}$ was then dried at $130^{\circ} \mathrm{C}$ for 3 hours in the oven. The activated NZ then washed again with $\mathrm{NH}_{4} \mathrm{Cl} 1 \mathrm{M}$ under stirring condition at $60{ }^{\circ} \mathrm{C}$ for 3 hours, filtered and washed repeatedly until no $\mathrm{Cl}^{-}$ ion are detected by $\mathrm{AgNO}_{3}$ solution. Finally, the activated $\mathrm{NZ}$ was dried in an oven at $130{ }^{\circ} \mathrm{C}$ for 3 hours. The activated NZ was resulted from this processes and called as acid activated natural zeolite (ANZ).

\section{Analysis and Characterization}

The phases of NZ and ANZ was characterized through X-ray diffraction using Philips X'pert type. The morphological surface was examined using SEM (JEOL, Tokyo, Japan). The total pore volume, pore size distribution and surface area (SBET) were determined using Quantachrome Instruments NOVA 1200 (High Speed Gas Sorption Analyzer Versions 10.0 - 10.03). pH was measured using Pasco pH meter (spark PS2008A) and the Cr(VI) concentration was determined by UV-Vis spectrophotometer type UV 1240 (Shimadzu, Japan).

\section{Sorption studies}

Batch system was used to investigate the adsorption of $\mathrm{Cr}(\mathrm{VI})$ on the $\mathrm{NZ}$ and $\mathrm{ANZ}$ particles from aqueous solution in order to obtain rate and equilibrium data. The kinetics study were carried out by adding the 0.4 $\mathrm{g} \mathrm{NZ}$ or ANZ in $50 \mathrm{~mL}$ glass beaker contained with $25 \mathrm{~mL}$ solution of $\mathrm{Cr}(\mathrm{VI})$ with initial concentration of $14 \mathrm{mg} / \mathrm{L}$ and $\mathrm{pH}$ 2. The sample was kept stirring in a thermostat shaker and adjusted at temperature $303 \mathrm{~K}$ with different contact time from 5 to 45 minutes separately. The concentration of $\mathrm{Cr}(\mathrm{VI})$ in liquid phase after the process was measured by UV-Vis spectrophotometer. Isotherms adsorption were found out through $\mathrm{Cr}(\mathrm{VI})$ adsorption onto $\mathrm{NZ}$ and $\mathrm{ANZ}$ particles data at different initial concentrations ranging from 6 to $14 \mathrm{mg} / \mathrm{L}$ at constant temperature $303 \mathrm{~K}$ respectively. After this period, the $\mathrm{Cr}(\mathrm{VI})$ concentration was analyzed by UV-Vis spectrophotometer at $540 \mathrm{~nm}$ using 1,5-diphenylcarbazide as the complexion agent. The adsorption capacity of $\mathrm{Cr}(\mathrm{VI})$ was calculated using the following equation:

$$
\mathrm{qe}=\frac{(\mathrm{Co}-\mathrm{Ce}) \mathrm{V}}{\mathrm{W}}
$$

Where $C o$ and $C$ e are the initial and equilibrium concentrations of $\mathrm{Cr}(\mathrm{VI})$ in solution; $V$ is the volume $(L)$; and $W$ is the mass $(\mathrm{g})$ of the adsorbent respectively. 


\section{Zeolites Characterization}

\section{RESULTS AND DISCUSSION}

XRD measurement indicates that the ANZ is mainly composed of $33.33 \%$ mordenite before activation and increase to $50 \%$ mordenite $\left(\mathrm{Ca}_{3.4} \mathrm{Al}_{7.4} \mathrm{Si}_{40.6} \mathrm{O}_{96}\left(\mathrm{H}_{2} \mathrm{O}\right)\right.$ after acid activation of NZ (Fig.- 1$)$. The data were obtained by comparing XRD spectra of NZ and ANZ with quartz patterns from ICCD standard number 01078-1253 and mordenite patterns from ICCD standard number 01-074-3677.
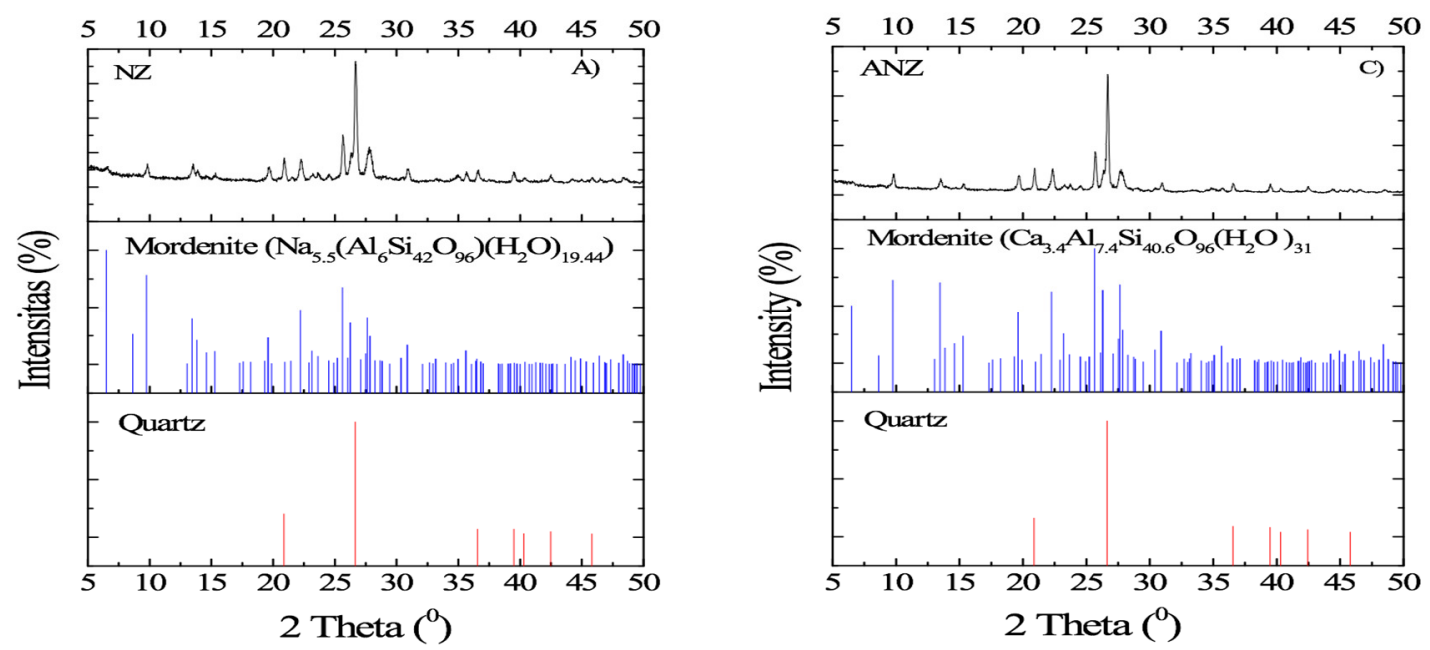

Fig.-1: XRD Spectra of NZ and ANZ

SEM characterization was conducted with the objective to know the surface morphological image of NZ and ANZ as shown in Fig.-2. Fig.-2a and Fig.-2b indicate that NZ has a smooth surface morphology may cause any non-adhesive impurities in NZ canal structures, whereas ANZ has more clearly opened structures. This result indicates that acid activation successfully removes impurities blocking the pore of zeolite and causes the increasing of pore diameter of zeolite where the SEM images showed that crystal of mordenite with crystal up to $20 \mu \mathrm{m}$ (Fig.-2c) and $2 \mu \mathrm{m}$ (Fig.-2d).
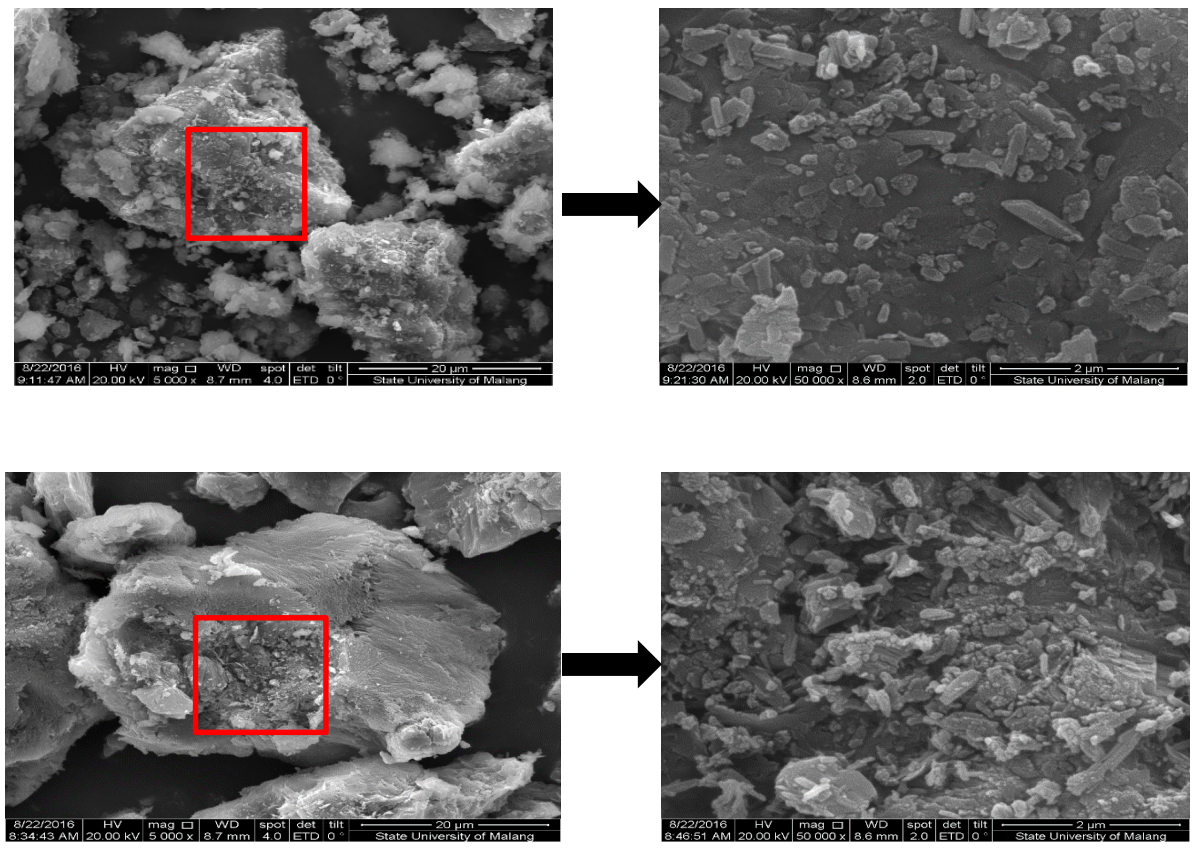

Fig.-2: SEM image of NZ and ANZ: (a) The NZ image was amplified in 5000x, (b) The NZ image was amplified in 50000x, (c) The ANZ image was amplified in 5000x and (d) The ANZ image was amplified in 50000x 
The BET characterization study was performed on the powder of NZ and ANZ to identify the effect of acid activation on the zeolite surface area and average of pore size diameter. Graphic describing isotherm adsorption/desorption of nitrogen on NZ and ANZ is presented in Fig.-3 and concluded at Table-1.

Figure- 3 shows that the adsorption process is categorized as adsorption type IV. In general, adsorption type IV indicates that both NZ and ANZ have the mesopore structures which generally have hysteresis loop at $\mathrm{P} / \mathrm{P} 0$ between $0.75-0.95$. As shown that the average of pore diameter distribution indicated by peak at $39.43 \AA(3.943 \mathrm{~nm})$ and $48.32 \AA(4.832 \mathrm{~nm})$ for NZ and $38.31 \AA(3.831 \mathrm{~nm})$ for ANZ respectively. This data means that NZ or ANZ has a very small pore. The similar range of pore size diameter average distribution was reported for Australian natural zeolite where average of pore size diameter is $40 \AA^{13}$. Table- 1 shows the physical parameters of $\mathrm{NZ}$ and $\mathrm{ANZ}$ measured by $\mathrm{N}_{2}$ adsorption-desorption isotherms. The findings show that the BET surface area was increased after acid activation as indicated by active sites formed not only on the first layer of NZ but on the second layers too. Pore total volume, mesopore volume and pore diameter size average were getting smaller indicating that the formation of active sites occurs on most channels of mesopores and micro pores existed in NZ.
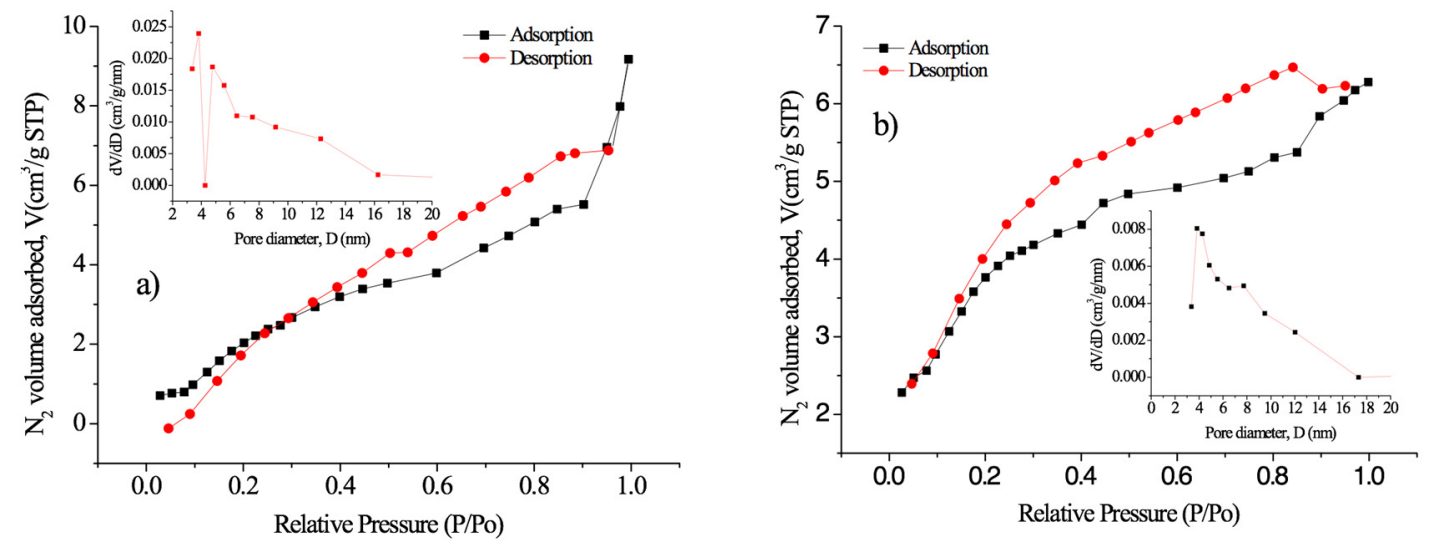

Fig.-3: $\mathrm{N}_{2}$ Adsorption-Desorption Isotherms and Pore Size Distribution of (a) NZ and (b) ANZ

Table-1: Physical parameters of NZ and ANZ measured by $\mathrm{N}_{2}$ adsorption-desorption isotherms

\begin{tabular}{c|c|c|c|c|c}
\hline Samples & $\begin{array}{c}\text { BET sur- } \\
\text { face area } \\
\left(\mathrm{m}^{2} / \mathrm{g}\right)\end{array}$ & $\begin{array}{c}\text { Total pore } \\
\text { volume } \\
\left(\mathrm{cm}^{3} / \mathrm{g}\right)\end{array}$ & $\begin{array}{c}\text { Micropore } \\
\text { volume } \\
\left(\mathrm{cm}^{3} / \mathrm{g}\right)\end{array}$ & $\begin{array}{c}\text { Mesopore } \\
\text { volume } \\
\left(\mathrm{cm}^{3} / \mathrm{g}\right)\end{array}$ & $\begin{array}{c}\text { Average of } \\
\text { pore size } \\
\text { diameter } \\
(\AA)\end{array}$ \\
\hline $\mathrm{NZ}$ & 12.928 & 0.0142 & 0.0000 & 0.0142 & $\begin{array}{c}39.43 ; \\
48.32\end{array}$ \\
\hline ANZ & 13.713 & 0.0097 & 0.0050 & 0.0047 & 38.33 \\
\hline
\end{tabular}

a: Multi point BET, b: total volume pore total at P/P0 = $0.9945(\mathrm{NZ})$ and $0.9984(\mathrm{ANZ})$, c: Mesopore volume $=$ Total pore volume - Micropore volume

\section{Kinetics Study}

Kinetics adsorption modeling was conducted in order to determine the controlling mechanism of sorption processes such as mass transfer and chemisorption. Here, pseudo-first and the pseudo-second order kinetic models were used to test the experimental data and was calculated using eq. 2 and 3 from Table-2. The kinetics model of adsorption Cr(VI) onto NZ and ANZ particles were shown in Fig.-4 and the results was presented in Table-3. Table-3 explains that the correlation coefficient $\left(\mathrm{R}^{2}\right)$ for $\mathrm{Cr}(\mathrm{VI})$ adsorption onto NZ and ANZ particle showed that the Pseudo-second order $>$ Pseudo-first order, which indicates that the 
RASĀYAN J. Chem.

Vol. 10 | No. 2 |606-612 | April - June | 2017

pseudo-second-order model is more suitable in describing the kinetics adsorption of $\mathrm{Cr}(\mathrm{VI})$ onto ANZ and NZ particles.

Table-2: Kinetics Model Equation

\begin{tabular}{l|l|c}
\hline \multicolumn{1}{c|}{ Kinetic models } & \multicolumn{1}{c|}{ Equation } & References \\
\hline Pseudo-first-order & $\ln \left(\mathrm{q}_{\mathrm{e}}-\mathrm{q}_{\mathrm{t}}\right)=\ln \mathrm{q}_{\mathrm{e}}-\mathrm{k}_{1} \mathrm{t}$ & 14 \\
\hline Pseudo-second-order & $\frac{\mathrm{t}}{\mathrm{qt}}=\frac{1}{\mathrm{k}_{2} \mathrm{qe}^{2}}+\frac{1}{\mathrm{qe}} \mathrm{t}$ & 15 \\
\hline
\end{tabular}

Table-3: The kinetic parameters of $\mathrm{Cr}(\mathrm{VI})$ adsorption onto NZ and ANZ

\begin{tabular}{c|c|c|c}
\hline \multirow{3}{*}{ Kinetic models } & Parameters & \multicolumn{2}{|c}{ Adsorbent } \\
\cline { 2 - 4 } & & $\mathrm{NZ}$ & $\mathrm{ANZ}$ \\
\hline \multirow{3}{*}{\begin{tabular}{c} 
Pseudo-first order \\
\cline { 2 - 4 }
\end{tabular}} & $\left.\mathrm{k}_{1} / 10^{-3}\right) / \mathrm{min}$ & 0.006 & 0.057 \\
\cline { 2 - 4 } & $\mathrm{q}^{2} /(\mathrm{mg} / \mathrm{g})$ & 0.069 & 0.130 \\
\hline \multirow{3}{*}{$\begin{array}{c}\text { Pseudo-second } \\
\text { order }\end{array}$} & $\left(\mathrm{k}_{2} / 10^{-3} \mathrm{~g}\right) /(\mathrm{mg} \cdot \mathrm{min})$ & 0.003 & 0.113 \\
\cline { 2 - 4 } & $\mathrm{qe}_{\mathrm{e}} /(\mathrm{mg} / \mathrm{g})$ & 0.017 & 0.037 \\
\cline { 2 - 4 } & $\left(\mathrm{h} / 10^{-2} \mathrm{mg}\right) /(\mathrm{g} \cdot \mathrm{min})$ & 0.042 & 0.074 \\
\cline { 2 - 4 } & $\mathrm{R}^{2}$ & 0.843 & 0.989 \\
\hline
\end{tabular}

\section{Isotherms Adsorption}

In general, an isotherm adsorption is defined as the phenomenon of retention or a substance mobility from liquid phase (the aqueous porous media or aquatic environments) to a solid-phase at a constant temperature and $\mathrm{pH}^{16-18}$. Langmuir isotherm is an empirical model which assumes that adsorption take place monolayer (the adsorbed layer is one molecule in thickness) where adsorption can only occur in a finite (fixed) number of definite localized sites, that are identical and equivalent, with no lateral interaction and steric hindrance between the adsorbed molecules, even on adjacent sites ${ }^{19}$. Meanwhile, the Freundlich isotherm assumes that the adsorption process takes place on heterogeneous surfaces and adsorption capacity is related to the $\mathrm{Cr}$ (VI) concentration at equilibrium.. Heterogeneity in Freundlich isotherms is indicated by the value of $n$. The $n$ value is larger than or equals to $1(n \geq 1)$ shows that the system is homogeneous and if the $n$ value lower than $1(\mathrm{n} \leq 1)$, the system is heterogeneous. Langmuir and Freundlich isotherm models were implemented to investigate this phenomenon and were calculated based on eq. 4 and eq. 5 from Table- 4 . As an illustration, plots for two isotherm model for NZ and ANZ are shown in Fig. -5 while the result are presented in Table-5. The result proves that isotherm data are better fitted by the Langmuir isotherm model than Freundlich model, which is indicated by higher $\mathrm{R}^{2}$ values for $\mathrm{Cr}(\mathrm{VI})$ adsorption on $\mathrm{NZ}$ and $\mathrm{ANZ}$. The Qmax in Langmuir model for NZ and ANZ are 0.819 and $1.040 \mathrm{mg} / \mathrm{g}$ respectively. Based on the value of $\mathrm{n}$, NZ has $\mathrm{n}=9832$ and $\mathrm{ANZ} \mathrm{n}=28,169$, this means the adsorption occurs in the homogeneous system. The adsorption process favorability of $\mathrm{Cr}(\mathrm{VI})$ adsorption on to ANZ was determined from Eq.(6):

$$
\mathrm{R}_{\mathrm{L}}=\frac{1}{1+\mathrm{K}_{\mathrm{L}} \mathrm{C}_{0}}
$$

An adsorption process is favorable if $0<\mathrm{R}_{\mathrm{L}}<1$ and considered unfavorable if $\mathrm{R}_{\mathrm{L}}>1$. The result showed that the $R_{\mathrm{L}}$ for ANZ at $303 \mathrm{~K}$ is 0.248 , this means that the ANZ was favorable for adsorption of $\mathrm{Cr}(\mathrm{VI})$. 
RASĀYAN J. Chem.

Vol. 10 | No. 2 |606-612 | April - June | 2017
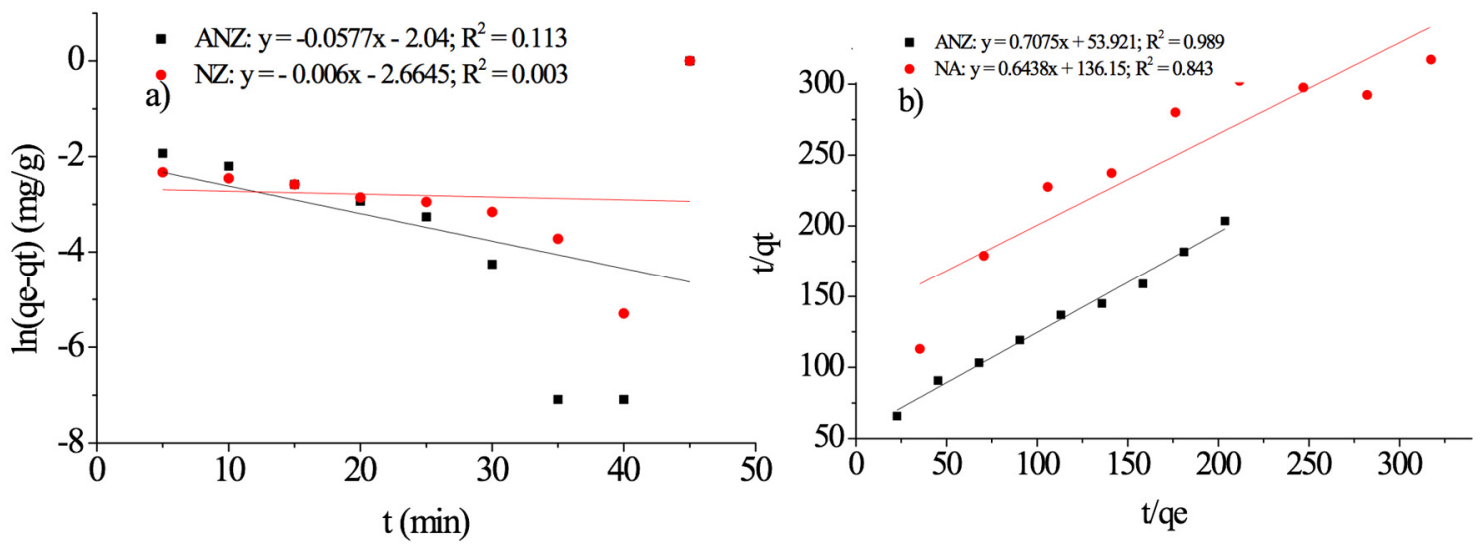

Fig.-4: Kinetic models of NZ and ANZ: (a) Pseudo-First Order and (b) Pseudo-Second Order
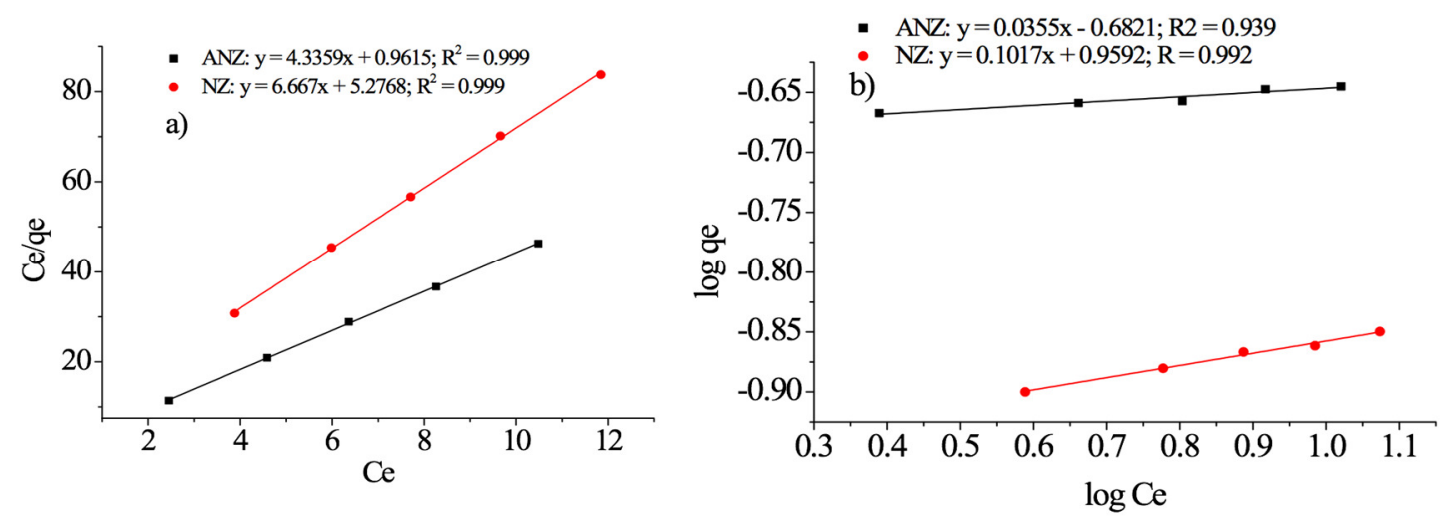

Fig.-5: Isotherm adsorption models: (a) Langmuir and (b) Freundlich

Table-4: Langmuir and Freundlich Isotherm Models Equations

\begin{tabular}{c|c|c}
\hline Isotherm models & \multicolumn{1}{|c|}{ Equation } & References \\
\hline Langmuir & $\frac{\mathrm{Ce}}{\mathrm{q}}=\frac{1}{K q \max }+\frac{1}{q \max } \mathrm{Ce}$ & 20 \\
\hline Freundlich & $\log \mathrm{q}=\log \mathrm{K}_{\mathrm{F}}+\frac{1}{\mathrm{n}} \log \mathrm{Ce}$ & 20 \\
\hline
\end{tabular}

Table-5: Isotherm parameters of $\mathrm{Cr}(\mathrm{VI})$ adsorption onto $\mathrm{NZ}$ and $\mathrm{ANZ}$

\begin{tabular}{c|c|c|c}
\hline \multirow{2}{*}{$\begin{array}{c}\text { Isotherm adsorption mod- } \\
\text { els }\end{array}$} & \multirow{2}{*}{ Parameters } & \multicolumn{2}{|c}{ Adsorbent } \\
\cline { 2 - 4 } & & $\mathrm{NZ}$ & $\mathrm{ANZ}$ \\
\hline \multirow{3}{*}{ Langmuir } & $\mathrm{Qmax}(\mathrm{mg} / \mathrm{g})$ & 0.189 & 1.040 \\
\cline { 2 - 4 } & $\mathrm{K}_{\mathrm{L}}(\mathrm{L} / \mathrm{mg})$ & 0.154 & 0.303 \\
\cline { 2 - 4 } & $\mathrm{R}^{2}$ & 0.999 & 0.999 \\
\hline Freundlich & $\mathrm{n}$ & 9.832 & 28.169 \\
\hline
\end{tabular}


RASĀYAN J. Chem.

Vol. 10 | No. 2 |606 - 612 | April - June | 2017

\begin{tabular}{c|c|c|c}
\hline & $\mathrm{KF}(\mathrm{mg} / \mathrm{kg})$ & 0.109 & 0.207 \\
\cline { 2 - 4 } & $\mathrm{R}^{2}$ & 0.992 & 0.939 \\
\hline
\end{tabular}

\section{CONCLUSION}

Indonesian (Ende Flores) natural zeolite was collected, activated and used for adsorption of $\mathrm{Cr}(\mathrm{VI})$. The adsorption kinetic model follows pseudo-second order while isotherm adsorption follows Langmuir isotherm. It is found that adsorption for $\mathrm{Cr}(\mathrm{VI})$ onto ANZ slightly higher than onto NZ with Qmax are 0.189 $\mathrm{mg} / \mathrm{g}$ and $1.040 \mathrm{mg} / \mathrm{g}$ for NZ and ANZ. Finally, the ANZ shows the favorability for Cr(VI) adsorption from aqueous solution.

\section{ACKNOWLEDGEMENT}

The First authors acknowledges a Doctoral Scholarship of the Ministry of Research, Technology and Higher Education, Republic of Indonesia.

\section{REFERENCES}

1. Y. Zeng, H. Woo, G. Lee and J. Park, Microporous Mesoporous Mater., 130, 83 (2010).

2. F. Venditti, F. Cuomo, A. Ceglie, L. Ambrosone and F. Lopez, J. Hazard. Mater., 173, 552 (2010).

3. D. D. Maksin, A. B. Nastasovic, A.D. Milutinovic-Nikolic, L.T. Surucic, Z.P. Sandi'c, R.V. Hercigonja and A.E. Onjia, J. Hazard. Mater., 210, 99 (2012).

4. Z. Kong, J. Wei, Y. Li, N. Liu, H. Zhang, Y. Zhang and L. Cui, Chem. Eng. J., 254, 365 (2014).

5. V.H. Waghmare and U.E. Chaudhari, Rasayan Journal of Chemistry, 10(1), 16 (2014)

6. K. Velumani1, P.E. Kumar and V. Sivakumar, Rasayan Journal of Chemistry, 9(2), 149 (2016)

7. A.K. Wanjari and U. E. Chaudhari, Rasayan Journal of Chemistry, 10(1), 82 (2017)

8. A. Alshameri, C. Yan, Y. Al-ani, A. Salman, A. Ibrahim, C. Zhou and H. Wang, J. Taiwan Inst. Chem. Eng., 45, 554 (2014).

9. R. Egashira, S. Tanabe and H. Habaki, Procedia Eng., 42, 49 (2012).

10. R. I. Yousef, B. El-eswed, M. Alshaaer, F. Khalili and H. Khoury, J. Hazard. Mater., 165, 379 (2009).

11. R. Leyva-Ramos, A. Jacobo-Azuara, P.E. Diaz-Flores, R.M. Guerrero-Coronado,J. Mendoza-Barron and M.S. Berber-Mendoza, Colloids and Surfaces A Physicochem. Eng. Asp., 330, 35 (2008).

12. Y.D. Ngapa, S. Sugiarti and Z. Abidin, Indones. J. Chem., 16(2), 138 (2016).

13. S. Wang and Z.H. Zhu, J. Hazard. Mater. B., 136, 946 (2006).

14. S. Yang, L. Li, Z. Pei, C. Li, J. Lv, J. Xie and B. Wen, Colloids Surfaces A Physicochem. Eng. Asp., 457, 100 (2014).

15. Y. Ho, J. Hazard. Mater. B., 136, 681 (2006).

16. G. Limousin, J. P. Gaudet, L. Charlet, S. Szenknect, V. Barthes and M. Krimissa, Appl. Geochem., 22, 249 (2007).

17. S. Bhuvaneshwari and V. Sivasubramanian, Chem. Eng. Comm., 201, 834 (2014).

18. S.J. Allen, G. Mckay and J.F. Porter, J. Colloid. Interface Sci., 280, 322 (2004).

19. K. Vijayaraghavan, T.V.N. Padmesh, K. Palanivelu and M. Velan, J. Hazard. Mater. B., 133, 304 (2006).

20. M. Erhayem, F. Al-Tohami, R. Mohamed, K. Ahmida, Am. J. Analyt. Chem., 1, 6 (2015).

[RJC-1710/2017] 